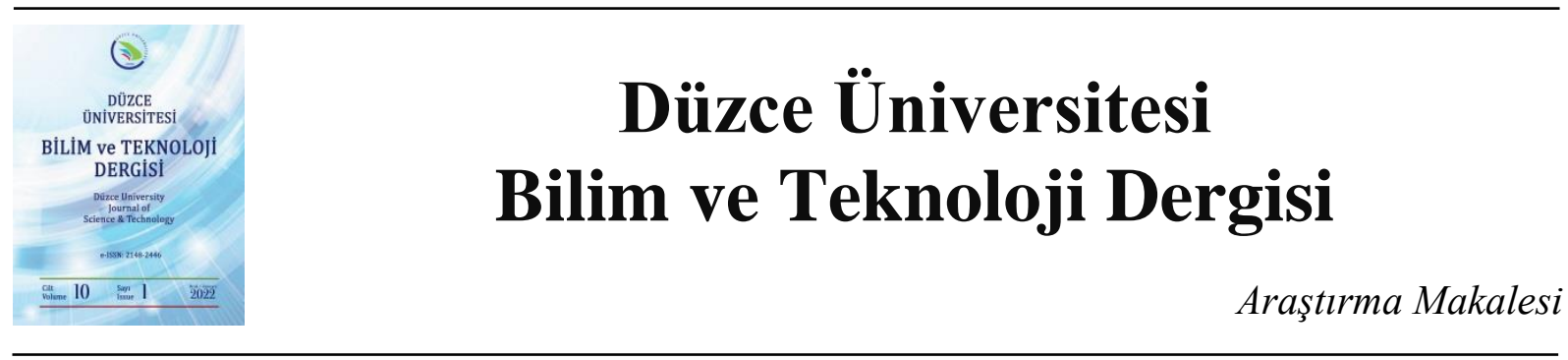

\section{Polimerik Malzeme Kaplı Atık Kâğıtlardan Üretilen Kompozitlerin Mekanik Özelliklerinin İstatistiksel Yöntemlerle İncelenmesi}

\author{
Birol ÜNER ${ }^{a}$, (iD) Zübeyde BÜLBÜL ${ }^{b^{*}}$ \\ ${ }^{a}$ Orman Endüstri Mühendisliği Bölümü, Orman Fakültesi, Isparta Uygulamalı Bilimler Üniversitesi, Isparta, \\ TÜRKIYYE \\ ${ }^{b}$ Malzeme ve Malzeme İşleme Teknolojileri Bölümü, Ormancılık Meslek Yüksekokulu, İstanbul Üniversitesi- \\ Cerrahpaşa, İstanbul, TÜRKIYYE \\ * Sorumlu yazarin e-posta adresi: zubeyde.bulbul@iuc.edu.tr \\ DOI:10.29130/dubited.825426
}

\begin{abstract}
$\underline{\mathrm{O} Z}$
Çalışmada çevre sorumluluğu bilinciyle atık tetrapak kağıtları ve PE (Polietilen) atıklar değerlendirilerek yeni bir kompozit malzeme elde edilmiştir. Bu birleştirme işlemi için dolgu maddeleri ve bağlayıcı ajanlar kullanılmıştır. Üretilen levhalar, fiziksel ve mekaniksel bazı özelliklerinin belirlenmesi için standartlara uygun biçimde kesilmiş ve deneysel çalışmalar yapılmıştır. Deneylerden elde edilen sonuçlar, istatistiksel yöntemlerle değerlendirilmiştir. Değerlendirme sonuçlarına göre, Tetrapak maddesine plastik ilave edildiği örneklerde ve bağlayıcı ajan olan maleik anhidritle kraftlanmış polietilen (MAPE) içeren kompozit örneklerinde mekanik direncin arttığı tespit edilmiştir. Eğilme dayanımlarının dolgu maddesinin çeşidi ve oranına bağlı olarak azaldığı, eşleştirici kimyasalların ise bazı deney gruplarının dışında eğilme dayanımını daha da azalttığı, elastikiyet modülü değerlerinde ise dolgu maddeleri ve eşleştiricilerin her ikisinin de değerleri düşürdüğ̈ ancak eşleştirici kimyasalların dolgu maddelerine nazaran bir miktar daha yüksek sonuçlar verdiği tespit edilmiştir.
\end{abstract}

Anahtar Kelimeler: Polietilen (PE), Polimer, Tetrapak atıklar, Mekanik özellikler

\section{Investigation of Mechanical Properties of Composites Produced from Polymeric Material Coated Waste Papers by Statistical Methods}

\begin{abstract}
In this study, a new composite material was obtained by evaluating waste tetrapak papers and PE (Polyethylene) wastes with the awareness of environmental responsibility.For this coupling process, fillers and binding agents were used. The composite plates were cut according to the standards in order to determine some physical and mechanical properties and experimental studies were conducted.The results obtained from the experiments were evaluated by statistical methods. According to the results of the evaluation was found that mechanical resistance increased in samples which plastic was added to Tetrapak and in composite samples containing polyethylene crafted with the coupling agent maleic anhydride (MAPE). The bending strength decreases depending on the type and proportion of the filling material, the matching chemicals (except for some experimental groups) reduced the bending strength,the fillers and the matchers decreased the values in the modulus of elasticity, but the matching chemicals gave some higher results than the fillers.
\end{abstract}

Keywords: Polyethylene (PE), Polymer, Tetrapak wastes, Mechanical properties

*Bu çalışma 'Polimerik Malzeme Kaplı Atık Kâğıt Ürünlerinden Kompozit Malzeme Üretimi’ isimli doktora tezinden türetilmiştir.

Geliş: 13/11/2020, Düzeltme:26/07/2021, Kabul: 01/08/2021 


\section{GIRIS}

Kompozitler birbiri içinde çözünmeyen iki yada daha fazla maddeden oluşan heterojen yapılı malzemelerdir. En azından bir faz, dağınık faz olarak çoğunlukla inorganiktir. Kompozitler kendilerini oluşturan maddelerden bağımsız olarak daha üstün mekanik özellikler ve performans özelliklerine sahip olarak tasarlanmaktadırlar [1].

Ağaç malzemenin higroskopik özellik taşıması, mantar, bakteri ve böcek arızlarına karşı koyamaması, yanabilir bir madde oluşu, heterojen yapısı ve farklı kısımlarında farklı mekanik özellik gösteren yapısıyla endüstride kısıtlı kullanım alanına sahip olan ağaç malzeme, çeşitli malzemelerle birleştirilip bir bütün oluşturduğunda farklı kullanım alanlarına sahip olmakta, mukavemet ve suya karşı dayanımı üst seviyelere ulaşmaktadır. Bu durumda atık kağıtların kompozit malzeme hammaddesi olarak kullanılması hem çevre duyarlılığına yaptığı katkıyla hem de sağladığı enerji tasarrufuyla endüstriye katk1 sağlamaktadır. Günümüzde atık maddelerin çevreye zarar vermeden geri dönüştürülmesi ve ekonomiye kazandırılması giderek önem kazanan bir konudur. Başta gelen geri dönüşüm malzemelerinden olan plastik ve kağıt hammaddeler kompozitlerin başlıca bileşenleridir.

Kompozit malzeme yapısı fiberler ve matrislerden oluşmaktadır. Birbirleri içerisinde çözünmeyen ve karışmayan bu malzemelerden matris; içerisine daha farklı bir fiber veya parçacık malzemenin konmasıyla tek bir yapı oluştururlar. Fiberler kompozit malzemede takviye elemanı olarak, mekanik mukavemeti sağlamakla görevlidirler. Fiberler arasında gerilim aktarımını sağlayan ve dolayısıyla mekanik dayanıklılığı etkileyen, fiberleri fiziksel ve kimyasal dış etkilerden koruyan matris, kompozit malzemelerin ana yapısını oluşturur. Matrislere (bağlayıcı) örnek olarak polimer, seramik ve metaller, güçlendiricilere örnek ise fiberler, partiküller, whiskerlar (polimer, seramik veya metalde olabilir) verilebilir [2]. Bu çalışma ile; kullanım süresi, sürdürülebilirlik, çevreye duyarlılık, doğada kaybolmayan plastik ve Tetrapak atıkların azaltılması ile enerji sektörüne katkıda bulunmak amaçlanmıştır. Tetrapak atıkların ekonomiye geri kazandırılması bu çalışmanın amaçlarından bir diğeridir. Elde edilen kompozit ürünlerle mekanik test sonuçlarına bakılarak mobilya, parke endüstrisi ve diş cephe kaplama da kullanılabilecek yeni bir alternatif bir malzeme amaçlanmıştır.

Takviye maddesi olarak mikrokristal selüloz, az miktarda odun unu ve matris malzeme olarak Polilaktik Asit (PLA) kullanılarak hazırlanan biyolojik çözünebilir kompozitlerin üretilip mekanik özelliklerinin test edildiği bir çalışmada; PLA kırılgan bir polimerdir ve selüloz takviyelerinin eklenmesiyle kırılganlığı daha da atmıştır. Kompozitlerin mekanik performansının takviyelerin en boy oranı, matrisin kristallik derecesi ve bileşenlerin yapışma verimliliğine bağlı olarak değiştiği ifade edilmiş̧ir. Odun unu kullanılan kompozitlerde mikrokristal selüloz kullanılan kompoztilere kıyasla daha iyi mekanik özellikte kompozitler ortaya çıktı̆̆ı belirtilmiştir [3].

Yüksek oranda selüloz lifleri ile kalsit ve kil mineralleri içeren kağıt üretim atıkları, ağırlıkça \%10-60 oranında yüksek yoğunluklu polietilen (YYPE) kompozit üretiminde kullanılarak kağıt üretim atığı katkısının mekanik özellikler üzerindeki etkisinin incelendiği bir araştırmaya göre; kompozitlerin eğilme dayanımının \%40 katkı içeren kompozitte \%26.3 oranında arttığı ortaya çıkmıştır. Modifikasyon ajanı kullanılmadan üretilen kompozitlerin mekanik özelliklerinde gelişme sağlandığı belirtilmiştir [4]. Dolgu maddesi olarak atık kağıt bardakların, polimer olarak atık Polipropilen (PP) ve Yüksek Yoğunluklu Polietilen (YYPE) maddelerinin ve uyum sağlayıcı olarak ise Maleik Anhidritle Kraftlanmış Polietilen (MAPE) 'nin kullanıldığı odun plastik kompozitlerinin mekanik özelliklerinin araştırıldığı çalışmada; en yüksek eğilme direnci değeri $(28.78 \mathrm{MPa})$, YYPE'in kullanıldığı kompozitlerde gözlemlenmiştir. Genel olarak mekanik değerler kullanılan kağıt bardak oranının artmasıyla artış göstermiştir [5]. 


\section{MATERYAL VE METOT}

\section{A. KULLANILAN MATERYAL}

Kompozit malzeme üretiminde Tetrapak malzemelere eklenen plastik ve çeşitli kimyasal eşleştirici maddeler şu şekilde sıralanmıştır; plastik malzeme, Kalsit, Borik Asit, Sodyum Perborat Tetrahidrat, Titanat, Asetik Asit, Maleik Anhidrit Graft edilmiş Polietilen, Viniltrietoksisilan.

Çalışmada; polimerik malzeme kaplı atık kağıt ürünleri (Tetrapak), Burdur da bir firmadan temin edilmiştir. Küçük parçalar halinde temin edilen kağıt ürünleri $1 \mathrm{~mm}$ 'lik bıçaklara sahip ögütücü makinesinde küçük toz parçacıklara dönüştürülmüştür. Polimerik malzemelerin toz haline dönüştürülmüş hali öncesi ve sonrası olarak Şekil 1'de gösterilmiştir. Polietilen, selüloz lifi ve bir miktarda alüminyum içeren atık kağıt malzemelerden farklı kimyasal maddeler içeren reçetelerle örnekler oluşturulmuştur.

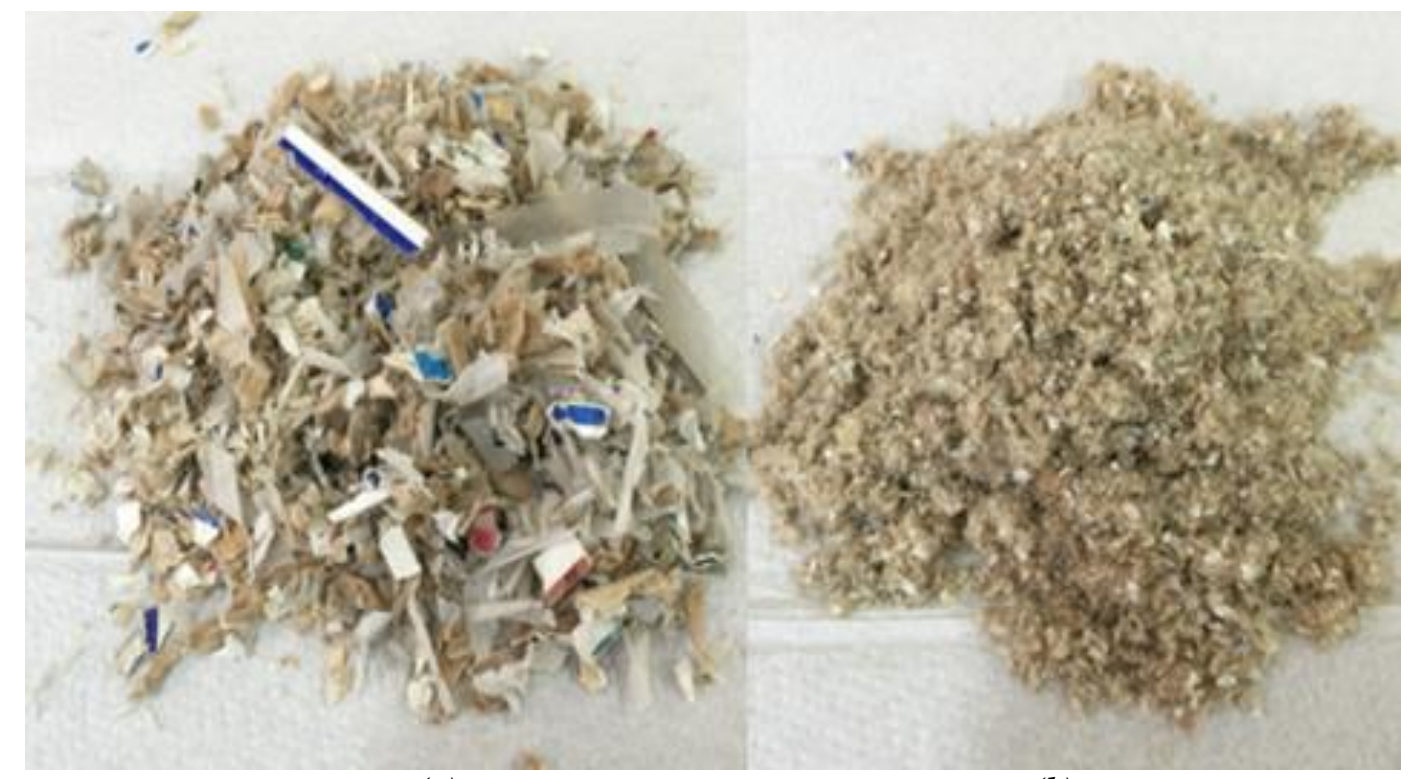

(a)

(b)

Şekil 1.Polimer malzemelerin; (a)öğ̈̈tülmeden önceki şekli, (b) öğ̈̈tüldükten sonraki şekli.

Tetrapak, tetrapak + plastik, tetrapak + plastik + eşleştirici kimyasal şeklinde farklı gruplarda toplam 38 adet kompozit malzeme Süleyman Demirel Üniversitesi, Orman Fakültesi, Orman Endüstri Mühendisliği laboratuvarında Çetinkaya Pres makinesinde 200 bar basınçla, $170{ }^{\circ} \mathrm{C}$ 1sıda yaklaşık $10^{\prime}$ ar $\mathrm{dk}$. alt ve üstten preslenerek $30 \times 30 \mathrm{~cm}$ büyüklüklerinde, $1 \mathrm{~cm}$ kalınlığında levhalar halinde üretilmiştir. Kompozit levhalar Tablo 1'de gösterilen koşullarda üretilmiştir.

Tablo 1.Kompozit levhalarının üretim koşulları

\begin{tabular}{cc}
\hline $\begin{array}{c}\text { Pres sicaklığ } 1 / \text { Alt Pres-Üst Pres } \\
\left({ }^{\circ} \mathrm{C}\right)\end{array}$ & $160-170$ \\
\hline $\begin{array}{c}\text { Pres süresi } \\
(\text { dakika })\end{array}$ & 10 \\
\hline $\begin{array}{c}\text { Pres basınc1 } \\
(\mathrm{N} / \mathrm{m} 2)\end{array}$ & 200 \\
\hline $\begin{array}{c}\text { Kalınlık } \\
(\mathrm{mm})\end{array}$ & 10 \\
\hline $\begin{array}{c}\text { Levha boyutları } \\
(\mathrm{cm})\end{array}$ & $30 \times 30$ \\
\hline
\end{tabular}


İlk üretilen kompozit levhada, toplamda 630 gr. öğütülmüş Tetrapak malzemeye \%10 (63 gr.) oranında plastik madde eklenmiştir. Daha sonra üretilen kompozit levhalarda bağlanmayı sağlaması için $\% 5, \% 15, \% 25$ oranlarında eşleştirici kimyasal maddeler ilave edilmiştir.

\section{A. 1. Mekanik Testler}

Kompozit malzemelerimizden 38 adedi Süleyman Demirel Üniversitesi Orman Fakültesi Orman Endüstri Mühendisliği Bölümü Mekanik Test Laboratuvarında bulunan 5 ton kapasiteli "Universal Test Cihazı" kullanılarak standartlara uygun olarak mekanik özellikleri test edilmiştir. Şekil 2'de mekanik test uygulaması gösterilmektedir.

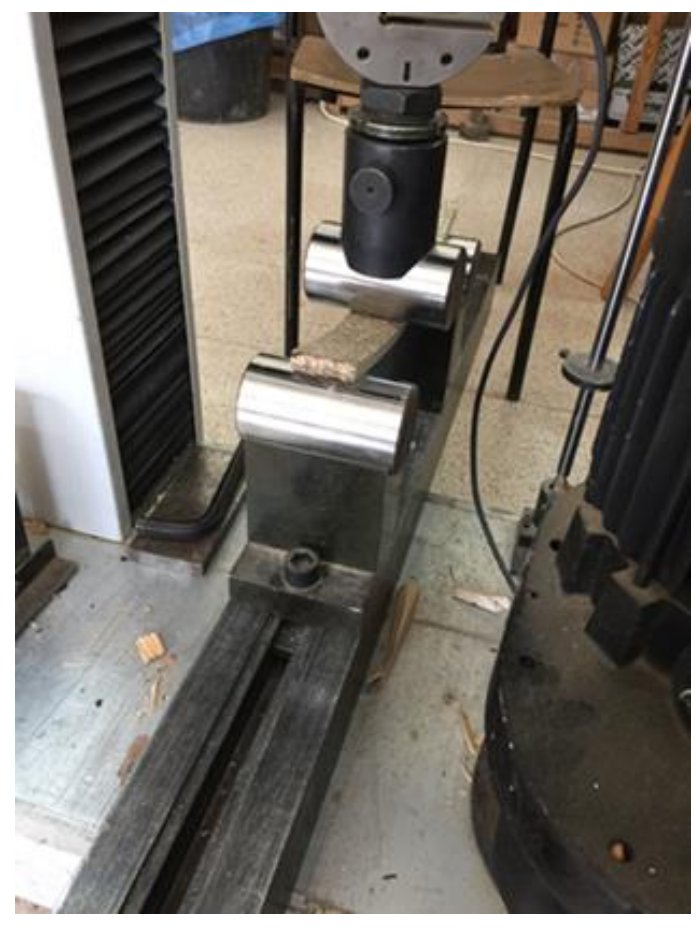

Şekil 2.Eğilme direnci ve ĕgilmede elastikiyet modülü tayini

Eğilme direnci ve eğilmede elastikiyet modülü testleri gösterilen Universal Test Makinesi kullanılarak gerçekleştirilmiştir. Deney parçaları dikdörtgen biçiminde olup 300x30x10 mm boyutlarında her çeşit kompozit malzemeden örnekler kesilmiştir. Buna göre eğilme direnci formülü Eşt. 1'de verilmiştir;

$\mathrm{Q}_{\mathrm{E}}=\frac{3 \mathrm{PL}}{2 \mathrm{bh}^{2}}$

Burada;

$\mathrm{QE}=(\mathrm{MOR})$ Eğilme direnci $(\mathrm{N} / \mathrm{mm} 2)$,

$\mathrm{P}=$ Kirılma anında uygulanan maksimum $\operatorname{kuvvet}(\mathrm{N})$,

$\mathrm{L}=$ Mesnetler arasi mesafe $(\mathrm{mm})$,

$\mathrm{h}=$ Örnek yüksekliği $(\mathrm{mm})$,

$\mathrm{b}=$ Örnek genişliği $(\mathrm{mm})$.

Eğilmede elastikiyet modülünün belirlenmesinde eğilme direnci deney örneklerinden yararlanılmıştır.

Eğilmede elastikiyet modülü formülü Eşt. 2'de verilmiştir;

$E=\frac{P \times L^{3}}{4 b \times h^{3} \times f}$

Burada,

E: Eğilmedeki elastikiyet modülü $\left(\mathrm{N} / \mathrm{mm}^{2}\right)$ 
P: Elastikiyet sınırı altında tatbik edilen yük $(\mathrm{N})$

L: Dayanak noktaları arasındaki açıklık ( $\mathrm{mm})$

b: Örnek genişliği (mm)

h: Örnek kalınlığı $(\mathrm{mm})$

f: Elastik bölgede P yüküne karşı örnekte meydana gelen deformasyon (mm)'dur.

\section{A. 2. İstatistiksel Değerlendirmeler}

Çalışmada kullanılan kontrol örnekleri, çeşitli eşleştirici kimyasallar bakımından farklılıkları ve dolgu maddeleri eklenmiş kompozit gruplarının mekanik özellikleri ile ilgili veriler Tek Yönlü Varyans analizi (One-WayAnova testi) ile değerlendirilmiş̦tir. Varyans analizinin normallik varsayımı mekanik özellikler bakımından kompozit gruplarına göre Shapiro-Wilk testi ile, eşit varyanslılık varsayımı ise Levene istatistiği ile denetlenmiştir. Varyans analizi sonucunda mekanik özellikler bakımından kompozit grupları arasında $\mathrm{P}=0,05$ anlamlılık düzeyinde istatistik bakımdan anlamlı ve önemli bir fark çıkması durumunda, farklı kompozit gruplarının belirlenmesi için Post-Hoc (Çoklu karşılaştırma) testlerden Tamhane T2 testi kullanılmıştır.

Anova; bağımsız değiş̧kende çok sayıda grup varsa ve üç ya da daha fazla ortalamanın eşit olup olmadığını test etmek amacıyla kullanılır. Bağımsız değişkenlerin kendi aralarında nasıl etkileşime girdiklerini ve buetkileşimlerin bağımlı değişken üzerindeki etkilerini analiz etmek için Anova kullanılır [6].

\section{BULGULAR}

\section{A. MEKANIK TEST BULGULARI VE ISTATISTIKSEL DEĞERLEDİIILMESI}

Kompozit levhalardan ilk hazırlanan örnek sadece tetrapak malzemeden oluşmakta ve $35 \times 31 \mathrm{~cm}$ boyutlarında, $1 \mathrm{~cm}$ kalınlığında ve $0,7595 \mathrm{~kg}$ ağırlığındadır. Kompozit çeşidi, tetrapak olarak adlandırılan bu levhadan 30x1x1 cm boyutlarında 2 adet örneğin eğilme direnci (MOR) ve elastikiyet modülü (MOE) hesaplamaları Tablo 2'de gösterilmiştir.

Tablo2.Tetrapak kompozit malzeme örneklerinin mekanik test sonuçları

\begin{tabular}{cccc}
\hline Kompozit Çeşidi & $\begin{array}{c}\text { Ortalama } \\
d\left(\mathrm{gr}_{\mathrm{cm}}{ }^{3}\right)\end{array}$ & $\begin{array}{c}\text { MOR } \\
\text { Ortalama } \\
\left(\mathrm{N} / \mathrm{mm}^{2}\right)\end{array}$ & $\begin{array}{c}\text { MOE } \\
\text { Ortalama } \\
\left(\mathrm{N} / \mathrm{mm}^{2}\right)\end{array}$ \\
\hline Tetrapak & 0,6082 & $\begin{array}{c}11,73 \\
(11,70)\end{array}$ & $\begin{array}{c}4675,22 \\
(3913,71)\end{array}$ \\
\hline
\end{tabular}

*Parantez içinde verilerin standart sapması gösterilmiştir.

Kompozit malzemelerden ikinci olarak hazırlanan örneğe birinciden faklı olarak palstik malzeme eklenmiştir. Örneğin toplam ağırlığı 630 gr.'dır. İçerisinde \%10'luk (63 gr.) plastik madde ve 567 gr. tetrapak malzemesi bulunmaktadır. Kompozit çeşidi, Tetrapak + Plastik olarak adlandırılan bu levhadan 30x1x1 cm boyutlarında 10 adet örneğin eğilme direnci ve elastikiyet modülü hesaplamaları Tablo 3'de gösterilmiştir.

Tablo3.Tetrapak + Plastik kompozit malzeme örneklerinin mekanik test sonuçları

\begin{tabular}{cccc}
\hline Kompozit Çeşidi & $\begin{array}{c}\text { Ortalama } \\
d\left(\mathrm{gr} / \mathrm{cm}^{3}\right)\end{array}$ & $\begin{array}{c}\text { MOR } \\
\text { Ortalama } \\
\left(\mathrm{N} / \mathrm{mm}^{2}\right)\end{array}$ & $\begin{array}{c}\text { MOE } \\
\text { Ortalama } \\
\left(\mathrm{N} / \mathrm{mm}^{2}\right)\end{array}$ \\
\hline $\begin{array}{c}\text { Tetrapak }+ \\
\text { Plastik }\end{array}$ & 0,6446 & $\begin{array}{c}14,39 \\
(2,57)\end{array}$ & $\begin{array}{c}7423,03 \\
(3368,79)\end{array}$ \\
\hline \multicolumn{2}{c}{${ }^{2}$ Parantez içinde verilerin standart sapmast gösterilmiştir. }
\end{tabular}


Tetrapak + Plastik + İnorganik madde olarak hazırlanan reçeteyle oluşturulan kompozit malzemelerin ilkinde kullanılan inorganik madde Kalsit $(\mathrm{CaCO} 3)$ 'dir. Toplamda 630 gr. tetrapak + plastik malzemeye eklenen \%5 (31 gr.), \%15 (94 gr.) ve \%25 (157 gr.) oranlarındaki Kalsitli örneklerden 4'er tane $30 \times 3 \times 1 \mathrm{~cm}$ boyutlarında hazırlanan örnekler direnç testlerine tabi tutulmuş ve sonuçları Tablo 4 'te gösterilmiştir.

Tablo4.Tetrapak + Plastik + Kalsitkompozit örneklerinin mekanik test sonuçları

\begin{tabular}{cccc}
\hline $\begin{array}{c}\text { Kompozit } \\
\text { Çeşidi }\end{array}$ & $\begin{array}{c}\text { Ortalama } \\
d\left(\mathrm{gr} / \mathrm{cm}^{3}\right)\end{array}$ & $\begin{array}{c}\text { MOR } \\
\text { Ortalama } \\
\left(\mathrm{N} / \mathrm{mm}^{2}\right)\end{array}$ & $\begin{array}{c}\text { MOE } \\
\text { Ortalama } \\
\left(\mathrm{N} / \mathrm{mm}^{2}\right)\end{array}$ \\
\hline$\% 5$ Kalsitli & 0,70 & $\begin{array}{c}13,57 \\
(4,64)\end{array}$ & $\begin{array}{c}588,57 \\
(157,86)\end{array}$ \\
\hline$\% 15$ Kalsitli & 0,75 & $\begin{array}{c}11,05 \\
(6,80)\end{array}$ & $\begin{array}{c}440,18 \\
(281,79)\end{array}$ \\
\hline$\% 25$ Kalsitli & 0,91 & $\begin{array}{c}9,43 \\
(4,35)\end{array}$ & $\begin{array}{c}375,28 \\
(155,30)\end{array}$ \\
\hline
\end{tabular}

*Parantez içinde verilerin standart sapması gösterilmiştir.

Tetrapak + Plastik + İnorganik madde olarak hazırlanan diğer kompozit malzeme çeşidinde inorganik madde olarak Borik Asit (H3BO3) kullanılmıştır. Toplamda 630 gr. Tetrapak + Plastik malzemeye eklenen \%5 (31 gr.), \%15 (94 gr.) ve \%25 (157 gr.) oranlarındaki Borik Asit'li örneklerden 4'er tane $30 \times 3 \times 1 \mathrm{~cm}$ boyutlarında hazırlanan örnekler direnç testlerine tabi tutulmuş ve sonuçları Tablo 5'te gösterilmiştir.

Tablo5.Tetrapak + Plastik + Borik Asit kompozit örneklerinin mekanik test sonuçlar

\begin{tabular}{cccc}
\hline Kompozit Çeşidi & $\begin{array}{c}\text { Ortalama } \\
d\left(\mathrm{gr}_{\mathrm{cm}} \mathrm{cm}^{3}\right)\end{array}$ & $\begin{array}{c}\text { MOR } \\
\text { Ortalama } \\
\left(\mathrm{N} / \mathrm{mm}^{2}\right)\end{array}$ & $\begin{array}{c}\text { MOE } \\
\text { Ortalama } \\
\left(\mathrm{N} / \mathrm{mm}^{2}\right)\end{array}$ \\
\hline$\% 5$ Borik Asitli & 0,68 & $\begin{array}{c}10,67 \\
(2,68)\end{array}$ & $\begin{array}{c}371,44 \\
(164,17)\end{array}$ \\
\hline$\% 15$ Borik Asitli & 0,56 & $\begin{array}{c}11,44 \\
(4,11)\end{array}$ & $\begin{array}{c}812,74 \\
(579,64)\end{array}$ \\
\hline$\% 25$ Borik Asitli & 0,74 & $\begin{array}{c}9,53 \\
(2,38)\end{array}$ & $\begin{array}{c}371,67 \\
(186,71)\end{array}$ \\
\hline
\end{tabular}

*Parantez içinde verilerin standart sapması gösterilmiştir.

Tetrapak + Plastik + İnorganik madde olarak hazırlanan diğer kompozit malzeme çeşidinde inorganik madde olarak SPT (Sodyum PerboratTetrahidrat / NaBO3.4H2O) ile $100 \mathrm{ml}$ 'lik Asetik Asit sulu çözeltisi eklenmiş; toplamda 630 gr. Tetrapak + Plastik malzemeye eklenen \%5 (31 gr.), \%15 (94 gr.) ve $\% 25$ (157 gr.) oranlarındaki SPT'li örneklerden 4'er tane $30 \times 3 \times 1 \mathrm{~cm}$ boyutlarında hazırlanan örnekler direnç testlerine tabi tutulmuş ve sonuçları Tablo 6' da gösterilmiştir.

Tablo6. Tetrapak + Plastik + SPT örneklerinin mekanik test sonuçları

\begin{tabular}{cccc}
\hline $\begin{array}{c}\text { Kompozit } \\
\text { Çeşidi }\end{array}$ & $\begin{array}{c}\text { Ortalama } \\
d\left(\mathrm{gr}_{\mathrm{cm}}{ }^{3}\right)\end{array}$ & $\begin{array}{c}\text { MOR } \\
\text { Ortalama } \\
\left(\mathrm{N} / \mathrm{mm}^{2}\right)\end{array}$ & $\begin{array}{c}\text { MOE } \\
\text { Ortalama } \\
\left(\mathrm{N} / \mathrm{mm}^{2}\right)\end{array}$ \\
\hline$\% 5 \mathrm{SPT}$ & 0,70 & $\begin{array}{c}12,36 \\
(3,20)\end{array}$ & $\begin{array}{c}494,48 \\
(194,25)\end{array}$ \\
\hline$\% 15 \mathrm{SPT}$ & 0,70 & $\begin{array}{c}7,26 \\
(0,76)\end{array}$ & $\begin{array}{c}456,83 \\
(23,99)\end{array}$ \\
\hline$\% 25 \mathrm{SPT}$ & 0,34 & 3,00 & 1783,03 \\
$(0,21)$ & $(1260,79)$ \\
\hline
\end{tabular}

*Parantez içinde verilerin standart sapması gösterilmiştir. 
Tetrapak + Plastik + Eşleştirici kimyasal madde olarak hazırlanan farklı kompozit malzeme çeşidinde eşleştirici kimyasal madde olarak \%3'lük Titanat kullanılmıştır. Toplam ağırlığı 630 gr. olan Tetrapak + Plastik karışımına 18 gr. Titanat eklenmiştir. Titanat'lı örnekler 4'er tane 30x3x1 cm boyutlarında hazırlanmış direnç testlerine tabi tutulmuş ve sonuçları Tablo7'de gösterilmiştir.

Tablo7. Tetrapak + Plastik + Titanatkompozit malzeme örneklerinin mekanik test sonuçları

\begin{tabular}{|c|c|c|c|}
\hline $\begin{array}{c}\text { Kompozit } \\
\text { Çeşidi }\end{array}$ & $\begin{array}{l}\text { Ortalama } \\
d\left(\mathrm{gr} / \mathrm{cm}^{3}\right)\end{array}$ & $\begin{array}{c}\text { MOR } \\
\text { Ortalama } \\
\left(\mathrm{N} / \mathrm{mm}^{2}\right) \\
\end{array}$ & $\begin{array}{c}\text { MOE } \\
\text { Ortalama } \\
\left(\mathrm{N} / \mathrm{mm}^{2}\right) \\
\end{array}$ \\
\hline $\begin{array}{c}\text { Tetrapak + } \\
\text { Titanat }\end{array}$ & 1,66 & $\begin{array}{c}8,89 \\
(2,86)\end{array}$ & $\begin{array}{c}435,41 \\
(165,67)\end{array}$ \\
\hline
\end{tabular}

Tetrapak + Plastik + İnorganikmadde + Eşleştirici kimyasal madde reçetesiyle hazırlanan kompozit malzemede inorganik madde olarak \%5 Borik Asit, eşleştirici kimyasal olarak \%3 Titanat eklenmiştir. Toplamda 0,630 gr. Tetrapak + Plastik malzemeye \%5 (31 gr.), \%15 (94 gr.), \%25 (157 gr.) Borik Asit ve $\% 3$ (18 gr.) Titanat eklenmiştir. Borik Asit + Titanat'l örnekler 4'er tane 30x3x1 cm boyutlarında hazırlanmış direnç testlerine tabi tutulmuş ve sonuçları Tablo8'de gösterilmiştir.

Tablo8. Tetrapak + Plastik + BorikAsit + Titanatkompozit malzeme örneklerinin mekanik test sonuçları

\begin{tabular}{cccc}
\hline Kompozit Çeşidi & $\begin{array}{c}\text { Ortalama } \\
d\left(\mathrm{gr} / \mathrm{cm}^{3}\right)\end{array}$ & $\begin{array}{c}\text { MOR } \\
\text { Ortalama } \\
\left(\mathrm{N} / \mathrm{mm}^{2}\right)\end{array}$ & $\begin{array}{c}\text { MOE } \\
\text { Ortalama } \\
\left(\mathrm{N} / \mathrm{mm}^{2}\right)\end{array}$ \\
\hline $\begin{array}{c}\text { \%5 Borik Asit } \\
+\% 3 \text { Titanat }\end{array}$ & 0,65 & $\begin{array}{c}5,66 \\
(2,71)\end{array}$ & $\begin{array}{c}645,20 \\
(842,78)\end{array}$ \\
\hline $\begin{array}{c}\text { \%15 Borik Asit } \\
+\% 3 \text { Titanat }\end{array}$ & 0,70 & $\begin{array}{c}6,95 \\
(3,83)\end{array}$ & $\begin{array}{c}9432,44 \\
(15888,59)\end{array}$ \\
\hline $\begin{array}{c}\text { \%25 Borik Asit } \\
+\% 3 \text { Titanat }\end{array}$ & 0,81 & $\begin{array}{c}4,94 \\
(0,74)\end{array}$ & $\begin{array}{c}150,45 \\
(55,32)\end{array}$ \\
\hline \multicolumn{2}{c}{ *Parantez içinde verilerin standart sapmast gösterilmiştir. }
\end{tabular}

Tetrapak + Plastik + İnorganikmadde + Eşleştirici kimyasal madde reçetesiyle hazırlanan kompozit malzemede inorganik madde olarak \%5 (31 gr.), \%15 (94 gr.), \%25 (157 gr.) Kalsit, eşleştirici kimyasal olarak \%3 (18 gr.). Kalsit + Titanat'lı örnekler 4'er tane 30x3x1 cm boyutlarında hazırlanmış direnç testlerine tabi tutulmuş ve sonuçları Tablo 9' da gösterilmiştir.

Tablo9.Tetrapak + Plastik + Kalsit + Titanatkompozit malzeme örneklerinin mekanik test sonuçları

\begin{tabular}{cccc}
\hline Kompozit Çeşidi & $\begin{array}{c}\text { Ortalama } \\
d\left(\mathrm{gr} / \mathrm{cm}^{3}\right)\end{array}$ & $\begin{array}{c}\text { MOR } \\
\text { Ortalama } \\
\left(\mathrm{N} / \mathrm{mm}^{2}\right)\end{array}$ & $\begin{array}{c}\text { MOE } \\
\text { Ortalama } \\
\left(\mathrm{N} / \mathrm{mm}^{2}\right)\end{array}$ \\
\hline $\begin{array}{c}\text { \%5 Kalsit } \\
\text { +\%3 Titanat }\end{array}$ & 0,77 & $\begin{array}{c}7,61 \\
(2,84)\end{array}$ & $\begin{array}{c}289,90 \\
(193,63)\end{array}$ \\
\hline \%15 Kalsit & 0,80 & 8,46 & 380,86 \\
$+\% 3$ Titanat & $(2,25)$ & $(224,74)$ \\
\hline \%25 Kalsit & 0,90 & 7,74 & 300,75 \\
+\%3 Titanat & $(2,41)$ & $(126,83)$ \\
\hline *Parantez icinde verilerin standart sapast
\end{tabular}

*Parantez içinde verilerin standart sapması gösterilmiştir.

Tetrapak + Plastik + İnorganikmadde + Eşleştirici kimyasal madde reçetesiyle hazırlanan kompozit malzemede inorganik madde olarak SPT + Asetik Asit, eşleştirici kimyasal madde olarak Titanateklenmiştir. Toplam ağırlığı 630 gr. olan Tetrapak + Plastik karışımına \%5 (31 gr.), \%15 (94 gr.) SPT + Asetik Asit ve \%3 (18 gr.) Titanat ilave edilmiştir. SPT + Asetik Asit + Titanat'lı örnekler, 
4'er tane 30x3x1 cm boyutlarındahazırlanmış direnç testlerine tabi tutulmuş ve sonuçları Tablo10'da gösterilmiştir.

Tablo 10. Tetrapak + Plastik + SPT + Titanat kompozit malzeme örneklerinin su alma ve mekanik test sonuçlar

\begin{tabular}{cccc}
\hline Kompozit Çeşidi & $\begin{array}{c}\text { Ortalama } \\
d\left(\mathrm{gr} / \mathrm{cm}^{3}\right)\end{array}$ & $\begin{array}{c}\text { MOR } \\
\text { Ortalama } \\
\left(\mathrm{N} / \mathrm{mm}^{2}\right)\end{array}$ & $\begin{array}{c}\text { MOE } \\
\text { Ortalama } \\
\left(\mathrm{N} / \mathrm{mm}^{2}\right)\end{array}$ \\
\hline \%5 SPT+ AA & 0,6307 & 8,92 & 582,93 \\
$+\% 3$ Titanat & $(1,24)$ & $(89,14)$ \\
\hline $\begin{array}{c}\text { \%15 SPT } \\
+ \text { AA+\%3 Titanat }\end{array}$ & 0,6512 & $\begin{array}{c}4,77 \\
(1,32)\end{array}$ & $\begin{array}{c}378,09 \\
(155,61)\end{array}$ \\
\hline \multicolumn{2}{c}{ *Parantez içinde verilerin standart sapmast gösterilmiştir. }
\end{tabular}

Tetrapak + Plastik + İnorganikmadde + Eşleştirici kimyasal madde reçetesiyle hazırlanan kompozit malzemede inorganik madde olarak \%5 Borik Asit, eşleştirici kimyasal olarak \%3 MAPE; Maleik Anhidrit Graft edilmiş Polietilen eklenmiştir.Toplamda 0,630 gr. Tetrapak + Plastik malzemeye \%5 (31 gr.), \%15 (94 gr.), \%25 (157 gr.) Borik Asit ve \%3 (18 gr.) MAPE eklenmiştir. Borik Asit + MAPE'li örnekler, 4'er tane $30 \times 3 \times 1 \mathrm{~cm}$ boyutlarında hazırlanmış ve direnç testlerine tabi tutulmuştur. Su alma test sonuçları Tablo 11'de gösterilmiştir.

Tablo 11. Tetrapak + Plastik + Borik Asit + MAPE kompozit malzeme örneklerinin mekanik test sonuçları

\begin{tabular}{|c|c|c|c|}
\hline Kompozit Çeşidi & $\begin{array}{l}\text { Ortalama } \\
d\left(\mathrm{gr} / \mathrm{cm}^{3}\right)\end{array}$ & $\begin{array}{c}\text { MOR } \\
\text { Ortalama } \\
\left(\mathrm{N} / \mathrm{mm}^{2}\right)\end{array}$ & $\begin{array}{c}\text { MOE } \\
\text { Ortalama } \\
\left(\mathrm{N} / \mathrm{mm}^{2}\right)\end{array}$ \\
\hline $\begin{array}{c}\% 5 \mathrm{BA}+ \\
\% 3 \mathrm{MAPE}\end{array}$ & 0,5940 & $\begin{array}{c}6,59 \\
(1,42)\end{array}$ & $\begin{array}{c}4123,73 \\
(1677,14)\end{array}$ \\
\hline $\begin{array}{l}\% 15 \mathrm{BA}+ \\
\% 3 \mathrm{MAPE}\end{array}$ & 0,6340 & $\begin{array}{c}5,39 \\
(1,42)\end{array}$ & $\begin{array}{c}3245,25 \\
(2020,49)\end{array}$ \\
\hline $\begin{array}{l}\% 25 \mathrm{BA}+ \\
\% 3 \mathrm{MAPE}\end{array}$ & 0,6880 & - & - \\
\hline
\end{tabular}

Tetrapak + Plastik + İnorganikmadde + Eşleştirici kimyasal madde reçetesiyle hazırlanan kompozit malzemede inorganik madde olarak \%5 SPT (Sodyum PerboratTetrahidrat / NaBO3.4H2O) ve 100 gr. Asetik Asit çözeltisi, eşleştirici kimyasal olarak \%3 MAPE; Maleik Anhidrit Graft edilmiş Polietilen eklenmiştir. Toplamda 0,630 gr. Tetrapak + Plastik malzemeye \%5 (31 gr.), \%15 (94 gr.), \%25 (157

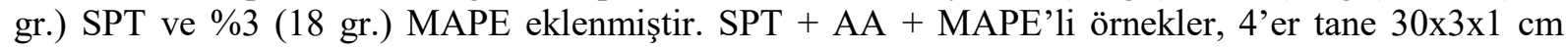
boyutlarında hazırlanmış direnç testlerinetabi tutulmuştur ve test sonuçları Tablo 12 'de gösterilmiştir.

Tablo 12. Tetrapak + Plastik $+S P T+A A+$ MAPE kompozit malzeme örneklerinin mekanik test sonuçları

\begin{tabular}{|c|c|c|c|}
\hline $\begin{array}{l}\text { Kompozit } \\
\text { Çeşidi }\end{array}$ & $\begin{array}{l}\text { Ortalama } \\
d\left(\mathrm{gr} \mathrm{cm}^{3}\right)\end{array}$ & $\begin{array}{c}\text { MOR } \\
\text { Ortalama } \\
\left(\mathrm{N} / \mathrm{mm}^{2}\right) \\
\end{array}$ & $\begin{array}{c}\text { MOE } \\
\text { Ortalama } \\
\left(\mathrm{N} / \mathrm{mm}^{2}\right) \\
\end{array}$ \\
\hline $\begin{array}{l}\% 5 \text { SPT+AA } \\
+\% 3 \mathrm{MAPE}\end{array}$ & 0,68 & $\begin{array}{c}6,16 \\
(1,23)\end{array}$ & $\begin{array}{c}3185,07 \\
(1460,44)\end{array}$ \\
\hline $\begin{array}{l}\% 15 \mathrm{SPT}+\mathrm{AA} \\
+\% 3 \mathrm{MAPE}\end{array}$ & 0,66 & $\begin{array}{c}6,08 \\
(0,01) \\
\end{array}$ & $\begin{array}{l}1197,51 \\
(486,85) \\
\end{array}$ \\
\hline $\begin{array}{c}\% 25 \mathrm{SPT}+\mathrm{AA} \\
+\% 3 \mathrm{MAPE}\end{array}$ & 0,70 & $\begin{array}{c}7,03 \\
(6,52)\end{array}$ & $\begin{array}{l}1049,00 \\
(868,04)\end{array}$ \\
\hline
\end{tabular}

*Parantez içinde verilerin standart sapması gösterilmiştir. 
Tetrapak + Plastik + İnorganikmadde + Eşleştirici kimyasal madde reçetesiyle hazırlanan kompozit malzemede inorganik madde olarak; Kalsit $\left(\mathrm{CaCO}_{3}\right)$, eşleştirici kimyasal olarak \%3 MAPE; Maleik Anhidrit Graft edilmiş Polietilen eklenmiştir. Toplamda 0,630 gr. Tetrapak + Plastik malzemeye \%5 (31 gr.), \%15 (94 gr.), \%25 (157 gr.) Kalsit ve \%3 (18 gr.) MAPE eklenmiştir. Kalsit + MAPE'li örneklerden 5'er tane $4 \times 4 \mathrm{~cm}$ 'lik parçalar su alma testi için hazırlanmış, 4'er tane $30 \times 3 \times 1 \mathrm{~cm}$ boyutlarında hazırlanan örnekler de direnç testlerine tabi tutulmuştur. Su alma test sonuçları Tablo 13 'de gösterilmiştir.

Tablo 13. Tetrapak + Plastik + Kalsit + MAPE kompozit malzeme örneklerinin mekanik test sonuçları

\begin{tabular}{cccc}
\hline $\begin{array}{c}\text { Kompozit } \\
\text { Çeşidi }\end{array}$ & $\begin{array}{c}\text { Ortalama } \\
d\left(\mathrm{gr}_{\mathrm{cm}}{ }^{3}\right)\end{array}$ & $\begin{array}{c}\text { MOR } \\
\text { Ortalama } \\
\left(\mathrm{N} / \mathrm{mm}^{2}\right)\end{array}$ & $\begin{array}{c}\text { MOE } \\
\text { Ortalama } \\
\left(\mathrm{N} / \mathrm{mm}^{2}\right)\end{array}$ \\
\hline $\begin{array}{c}\text { \%5 Kalsit }+ \\
\text { \%3 MAPE }\end{array}$ & 0,65 & $\begin{array}{c}4,05 \\
(-)\end{array}$ & $\begin{array}{c}1089,24 \\
(-)\end{array}$ \\
\hline $\begin{array}{c}\text { \%15 Kalsit+ } \\
\text { \%3 MAPE }\end{array}$ & 0,62 & $\begin{array}{c}5,76 \\
(1,42)\end{array}$ & $\begin{array}{c}2743,28 \\
(1473,72)\end{array}$ \\
\hline $\begin{array}{c}\text { \%25 Kalsit+ } \\
\text { \%3 MAPE }\end{array}$ & 0,69 & $\begin{array}{c}6,54 \\
(1,40)\end{array}$ & $\begin{array}{c}4860,88 \\
(3773,37)\end{array}$ \\
\hline \multicolumn{3}{c}{ *Parantez içinde verilerin standart sapmast gösterilmiştir. }
\end{tabular}

Tetrapak + Plastik + İnorganikmadde + Eşleştirici kimyasal madde reçetesiyle hazırlanan kompozit malzemede inorganik madde olarak; Kalsit $\left(\mathrm{CaCO}_{3}\right)$, eşleştirici kimyasal olarak \%3 SiLANIL; Viniltrietoksisilan $\mathrm{C}_{8} \mathrm{H}_{18} \mathrm{O}$ eklenmiştir. Toplamda 0,630 gr. Tetrapak + Plastik malzemeye \%5 (31 gr.), $\% 15$ (94 gr.), \%25 (157 gr.) Kalsit ve \%3 (18 gr.) SíLANiL eklenmiştir. Kalsit + SíLANIL'liörnekler 4'er tane 30x3x1 cm boyutlarında hazırlanmış direnç testlerine tabi tutulmuştur ve mekanik test sonuçları Tablo 14'te gösterilmiştir.

Tablo 14. Tetrapak + Plastik + Kalsit + SíLANIL kompozit malzeme örneklerinin su alma test sonuçları

\begin{tabular}{|c|c|c|c|}
\hline $\begin{array}{l}\text { Kompozit } \\
\text { Çeşidi }\end{array}$ & $\begin{array}{l}\text { Ortalama } \\
d\left(\mathrm{gr} / \mathrm{cm}^{3}\right)\end{array}$ & $\begin{array}{c}\text { MOR } \\
\text { Ortalama } \\
\left(\mathrm{N} / \mathrm{mm}^{2}\right)\end{array}$ & $\begin{array}{c}\text { MOE } \\
\text { Ortalama } \\
\left(\mathrm{N} / \mathrm{mm}^{2}\right)\end{array}$ \\
\hline $\begin{array}{c}\% 5 \text { Kalsit } \\
+\% 3 \text { SILANIL }\end{array}$ & 0,64 & $\begin{array}{c}7,60 \\
(1,77)\end{array}$ & $\begin{array}{c}5137,84 \\
(1395,33) \\
\end{array}$ \\
\hline $\begin{array}{c}\% 15 \text { Kalsit } \\
+\% 3 \text { SILLANIL } \\
\end{array}$ & 0,71 & $\begin{array}{c}770,07 \\
(557,77) \\
\end{array}$ & $\begin{array}{c}2327,67 \\
(2381,09) \\
\end{array}$ \\
\hline $\begin{array}{c}\% 25 \text { Kalsit } \\
+\% 3 \text { SILLANIL } \\
\end{array}$ & 0,64 & $\begin{array}{c}8,66 \\
(3,04) \\
\end{array}$ & $\begin{array}{c}3219,19 \\
(1772,09) \\
\end{array}$ \\
\hline
\end{tabular}

Tetrapak + Plastik + İnorganikmadde + Eşleştirici kimyasal madde reçetesiyle hazırlanan kompozit malzemede inorganik madde olarak; Borik Asit $\left(\mathrm{B}(\mathrm{OH})_{3}\right)$, eşleştirici kimyasal olarak \%3 SİLANIL; Viniltrietoksisilan $\mathrm{C}_{8} \mathrm{H}_{18} \mathrm{O}_{3} \mathrm{Si}$ eklenmiştir. Toplamda 0,630 gr. Tetrapak + Plastik malzemeye \%5 (31 gr.), \%15 (94 gr.), \%25 (157 gr.) Borik Asit ve \%3 (18 gr.) SİLANIL eklenmiştir. Borik Asit + SİLANIL'li örnekler 4'er tane $30 \times 3 \times 1 \mathrm{~cm}$ boyutlarında hazırlanmış vedirenç testlerine tabi tutulmuştur. Mekanik test sonuçları Tablo 15'te gösterilmiştir. 
Tablo 15. Tetrapak + Plastik + BorikAsit + SíLANÍL kompozit malzeme örneklerinin mekanik test sonuçları

\begin{tabular}{cccc}
\hline $\begin{array}{c}\text { Kompozit } \\
\text { Çeșidi }\end{array}$ & $\begin{array}{c}\text { Ortalama } \\
d\left(\mathrm{gr}_{\mathrm{cm}} \mathrm{cm}^{3}\right)\end{array}$ & $\begin{array}{c}\text { MOR } \\
\text { Ortalama } \\
\left(\mathrm{N} / \mathrm{mm}^{2}\right)\end{array}$ & $\begin{array}{c}\text { MOE } \\
\text { Ortalama } \\
\left(\mathrm{N} / \mathrm{mm}^{2}\right)\end{array}$ \\
\hline $\begin{array}{c}\text { \%5 BA + } \\
\text { \%3 SiLANIL }\end{array}$ & 0,60 & - & - \\
\hline $\begin{array}{c}\text { \%15 BA + } \\
\text { \%3 SILANIL }\end{array}$ & 0,57 & 8,38 & $\begin{array}{c}2205,80 \\
(748,62)\end{array}$ \\
\hline $\begin{array}{c}\text { \%25 BA + } \\
\text { \%3 SILLANIL }\end{array}$ & 0,60 & $\begin{array}{c}7,12 \\
(2,75)\end{array}$ & $\begin{array}{c}2241,82 \\
(1688,23)\end{array}$ \\
\hline \multicolumn{3}{c}{ *Parantez içinde verilerin standart sapması gösterilmistir. }
\end{tabular}

*Parantez içinde verilerin standart sapması gösterilmiştir.

Tetrapak + Plastik + İnorganikmadde + Eşleştirici kimyasal madde reçetesiyle hazırlanan kompozit malzemede inorganik madde olarak \%5 SPT (Sodyum PerboratTetrahidrat / $\mathrm{NaBO}_{3 \cdot 4} \mathrm{H}_{2} \mathrm{O}$ ) ve 100 gr. Asetik Asit çözeltisi, eşleştirici kimyasal olarak \%3 SILANIL; Viniltrietoksisilan $\mathrm{C}_{8} \mathrm{H}_{18} \mathrm{O}$ eklenmiştir. Toplamda 0,630 gr. Tetrapak + Plastik malzemeye \%5 (31 gr.), \%15 (94 gr.), \%25 (157 gr.) SPT ve $\% 3$ (18 gr.) SİLANIL Viniltrietoksisilan $\mathrm{C}_{8} \mathrm{H}_{18} \mathrm{O}$ eklenmiştir. SPT + AA + SİLANIL'li örnekler 4'er tane30x3x1 cm boyutlarında hazırlanmış direnç testlerine tabi tutulmuştur ve test sonuçları Tablo16' da gösterilmiştir.

Tablo 16. Tetrapak + Plastik $+S P T+A A+$ SiLANIL kompozit malzeme örneklerinin mekanik test sonuçlarl

\begin{tabular}{cccc}
\hline Kompozit Çeşidi & $\begin{array}{c}\text { Ortalama } \\
d\left(\mathrm{gr} / \mathrm{cm}^{3}\right)\end{array}$ & $\begin{array}{c}\text { MOR } \\
\text { Ortalama } \\
\left(\mathrm{N} / \mathrm{mm}^{2}\right)\end{array}$ & $\begin{array}{c}\text { MOE } \\
\text { Ortalama } \\
\left(\mathrm{N} / \mathrm{mm}^{2}\right)\end{array}$ \\
\hline $\begin{array}{c}\text { \%5 SPT + AA + } \\
\text { \%3 SiLANIL }\end{array}$ & 0,53 & $\begin{array}{c}310,13 \\
(600,65)\end{array}$ & $\begin{array}{c}1576,44 \\
(3142,60)\end{array}$ \\
\hline $\begin{array}{c}\text { \%15 SPT + AA + } \\
\text { \%3 SiLANIL }\end{array}$ & 0,65 & 3,29 & - \\
\hline $\begin{array}{c}\text { \%25 SPT + AA + } \\
\text { \%3 SiLANIL }\end{array}$ & 0,63 & - & - \\
\hline \multicolumn{2}{c}{ *Parantez içinde verilerin standart sapmast gösterilmiştir. }
\end{tabular}

Çalışmada üretilen kompozit levhaların bazı gruplarının; gerek örnek sayısının az oluşu gerek normal dağılış göstermemeleri, gerekse aşırı uç değerlerin olması dolayısıyla; eğilme direnci ve elastikiyet modülü değerleri analizden çıkarılmıştır.Eğilme direncinde analizden çıkarılan gruplar; Tetrapak + Plastik, \%5-15-25 SPT + AA + \%3 MAPE, \%5-15-25 Kalsit + \%3 MAPE, \%5-15-25 Kalsit + \%3 Silanil, \%5 SPT + AA + \%3 Silanil. Elastikiyet modülünde analizden çıkarılan gruplar; Tetrapak+ Plastik, \%5-15-25 Borik Asit, \%5-15-25 SPT + AA, \%5-15-25 Borik Asit + \%3 Titanat, \%5-15-25 Kalsit $+\% 3$ Silanil, \%5-15 SPT + AA + \%3 Silanil. Elastikiyet modülü analizinden çıkarılan gruplar; Tetrapak, \%5-15-25 BA, \%5-15-25 SPT + AA, \%5-15-25 BA + \%3 Titanat, \%5-15-25 Kalsit + \%3 Silanil, \%5-15 SPT + AA + \%3 Silanil'dir.

\section{A. 1. Ĕ̆ilme Direnci (MOR) İstatistiksel Bulguları}

Eğilme direnci testine tabi tutulan kompozit malzeme örneklerinden olan; Tetrapak + Plastik, \%5-1525 Kalsitli, \%5-15-25 Borik Asitli, \%5-15-25 SPT + AA, Tetrapak + Plastik + \%3 Titanat, \%5-15-25 Borik Asit + \%3 Titanat, \%5-15-25 Kalsit + \%3 Titanat, \%5-15 SPT + AA + \%3Titanat, \%5-15 Borik Asit + \%3 MAPE, \%15-25 Borik Asit + \%3 Silanil'in eğilme direnci bakımından farklılıkları Varyans analizi ile ortaya konmuştur. Eğilme direnci ölçülen 10 farklı kompozitgruplarına ait değerlere Normal Dağılım uygunluğu Shapiro-Wilk testi ile denetlenmiştir. Normallik Test sonuçları Tablo 17'de gösterilmiştir. 
Tablo 17. Kompozit çeşitlerinin eğilme dirençlerine göre Normallik Testi

\begin{tabular}{cccc}
\hline \multirow{2}{*}{ Kompozit Çeşidi } & \multicolumn{3}{c}{ Shapiro-Wilk } \\
\cline { 2 - 4 } & $\begin{array}{c}\text { İstatistikler } \\
(\text { Statistic })\end{array}$ & $\begin{array}{c}\text { Serbestlik } \\
\text { Derecesi } \\
(D f)\end{array}$ & $\begin{array}{c}\text { Önem Düzeyi } \\
p \text { (Sig.) }\end{array}$ \\
\hline Tetrapak+ Plastik & 0,855 & 10 & 0,066 \\
\hline \%5-15-25 Kalsitli & 0,922 & 12 & 0,304 \\
\hline \%5-15-25 Borik Asitli & 0,878 & 12 & 0,084 \\
\hline \%5-15-25 SPT+ AA & 0,933 & 10 & 0,481 \\
\hline Tetrapak+ Plastik + \%3 Titanat & 0,950 & 4 & 0,717 \\
\hline \%5-15-25 Borik Asit +\%3 Titanat & 0,952 & 11 & 0,671 \\
\hline \%5-15 Spt + Aa+ \%3 Titanat & 0,929 & 12 & 0,369 \\
\hline \%5-15 Borik Asit + \%3 Mape & 0,964 & 8 & 0,849 \\
\hline \%15-25 Borik Asit + \%3 Silanil & 0,849 & 8 & 0,092 \\
\hline & 0,875 & 10 & 0,113 \\
\hline
\end{tabular}

Test sonucunda eğilme direnci bakımından tüm grupların önem düzeyi değerleri $\mathrm{P}>0,05$ olduğu için tüm gruplar normal dağılım göstermektedir.

Kompozit gruplarının eğilme direncine ait tanımlayıcı istatistikler Tablo 18'de gösterilmiştir.

Tablo 18. Eğilme direnci testi yapılan kompozit çeşitlerinin tanımlayıcı istatistik değerleri

\begin{tabular}{|c|c|c|c|c|c|}
\hline $\begin{array}{l}\text { Kompozit } \\
\text { Çeşidi }\end{array}$ & $\begin{array}{l}\text { Kompozit } \\
\text { Sayısı } \\
(N)\end{array}$ & Ort. & $\begin{array}{c}\text { Standard } \\
\text { Sapma } \\
(S t d)\end{array}$ & $\begin{array}{c}\text { Minimum } \\
\text { Değerler }\end{array}$ & $\begin{array}{l}\text { Maksimum } \\
\text { Değerler }\end{array}$ \\
\hline Tetrapak + Plastik & 10 & 14,39 & 2,57 & 9,46 & 16,78 \\
\hline$\% 5-15-25$ Kalsitli & 12 & 11,35 & 5,18 & 4,22 & 20,45 \\
\hline $\begin{array}{c}\% 5-15-25 \text { Borik } \\
\text { Asitli } \\
\end{array}$ & 12 & 10,55 & 2,97 & 7,28 & 16,26 \\
\hline $\begin{array}{c}\% 5-15-25 \mathrm{Spt}+ \\
\mathrm{Aa}\end{array}$ & 10 & 8,45 & 4,20 & 2,85 & 15,63 \\
\hline $\begin{array}{c}\text { Tetrapak + Plastik } \\
+\% 3 \text { Titanat }\end{array}$ & 4 & 8,90 & 2,87 & 5,13 & 11,64 \\
\hline $\begin{array}{c}\% 5-15-25 \text { Borik } \\
\text { Asit }+\% 3 \text { Titanat }\end{array}$ & 11 & 5,75 & 2,45 & 2,49 & 10,01 \\
\hline $\begin{array}{c}\% 5-15-25 \text { Kalsit } \\
\text { + \%3 Titanat }\end{array}$ & 12 & 7,94 & 2,31 & 4,10 & 11,01 \\
\hline $\begin{array}{c}\% 5-15 \mathrm{Spt}+\mathrm{Aa}+ \\
\% 3 \text { titanat }\end{array}$ & 8 & 6,85 & 2,51 & 3,20 & 10,22 \\
\hline $\begin{array}{l}\% 5-15 \text { Borik Asit } \\
\text { +\%3 Mape }\end{array}$ & 8 & 5,84 & 1,45 & 4,09 & 7,43 \\
\hline $\begin{array}{c}\% 15-25 \text { Borik } \\
\text { Asit }+\% 3 \text { Silanil }\end{array}$ & 10 & 7,75 & 2,41 & 3,44 & 10,27 \\
\hline Genel & 97 & 8,91 & 3,97 & 2,49 & 20,45 \\
\hline
\end{tabular}

Tanımlayıcı istatistik tablosunda her bir kompozit çeşidinde kaç örnek bulunduğu, bunların ortalama değerleri ile bunlara ait standart sapma değerleri yer almaktadır.Tabloda kompozit çeşitlerinin içerdikleri katkı maddeleri ve kimyasal çeşitleri arttıkça eğilme dirençlerinin düştüğü görülmektedir. Eğilme dirençleri bakımından kompozit çeşitleri varyans analizi ile karşılaştırılmış ve sonuçlar Tablo 19'da gösterilmiştir. 
Tablo 19. Varyans Analizi tablosu

\begin{tabular}{|c|c|c|c|c|c|}
\hline & $\begin{array}{l}\text { Kareler } \\
\text { Toplamı }\end{array}$ & $\begin{array}{c}\text { Serbestlik } \\
\text { Derecesi } \\
(d f)\end{array}$ & $\begin{array}{c}\text { Kareler } \\
\text { Ortalaması }\end{array}$ & $\mathbf{F}$ & $\begin{array}{l}\text { Önem } \\
\text { Düzeyi }\end{array}$ \\
\hline $\begin{array}{c}\text { Gruplar } \\
\text { Aras1 }\end{array}$ & 649,950 & 9 & 72,217 & & \multirow{3}{*}{0,000} \\
\hline $\begin{array}{c}\text { Gruplar } \\
\text { İçi }\end{array}$ & 866,044 & 87 & \multirow[t]{2}{*}{9,955} & 7,255 & \\
\hline Toplam & 1515,994 & 96 & & & \\
\hline
\end{tabular}

Anova tablosunda önem düzeyi $\mathrm{P}<0,05$ olduğu için gruplar arasında incelenen eğilme dirençleri bakımından istatistiksel anlamlı ve önemli bir fark olduğu görülmektedir. Hangi grupların ortalama değerleri arasında farklılıklar olduğu Tamhane T2 testi ile belirlenmiştir.

\section{A. 2. Eğilmede Elastikiyet Modülü (MOE) İstatistiksel Bulguları}

Eğilme direnci testine tabi tutulan kompozit malzeme örneklerinden olan; Tetrapak + Plastik,\%5-1525 Kalsitli, Tetrapak + Plastik + \%3Titanat, \%5-15-25 Kalsit + \%3 Titanat, \%5-15 SPT + AA + \%3Titanat, \%5-15 Borik Asit + \%3 MAPE, \%5-15-25 SPT + AA + \%3 MAPE, \%5-15-25 Kalsit + \%3 MAPE, \%15-25 Borik Asit + \%3 Silanil'in eğilmede elastikiyet modülü bakımından farklılıkları Varyans analizi ile ortaya konmuştur. Elastikiyet modülü ölçülen 9 farklı kompozit gruplarına ait değerlere Normal Dağılım uygunluğu Shapiro-Wilk testi ile denetlenmiştir. Normallik Test sonuçları Tablo 21'de gösterilmiştir.

Tablo 21. Kompozit çeşitlerinin elastikiyet modüllerine göre Normallik Testi

\begin{tabular}{|c|c|c|c|}
\hline \multirow[b]{2}{*}{ Kompozit Çeşidi } & \multicolumn{3}{|c|}{ Shapiro-Wilk } \\
\hline & $\begin{array}{l}\text { İstatistikler } \\
\text { (Statistic) }\end{array}$ & $\begin{array}{c}\text { Serbestlik } \\
\text { Derecesi } \\
(d f)\end{array}$ & $\begin{array}{c}\text { Önem Düzeyi } \\
p \text { (Sig.) }\end{array}$ \\
\hline Tetrapak + Plastik & 0,890 & 10 & 0,168 \\
\hline$\% 5-15-25$ Kalsitli & 0,959 & 12 & 0,774 \\
\hline Tetrapak + Plastik + \%3 Titanat & 0,942 & 4 & 0,668 \\
\hline$\% 5-15-25$ Kalsit $+\% 3$ Titanat & 0,936 & 12 & 0,447 \\
\hline$\% 5-15 \mathrm{SPT}+\mathrm{AA}+\% 3$ Titanat & 0,928 & 8 & 0,499 \\
\hline$\% 5-15$ Borik Asit + \%3 MAPE & 0,920 & 8 & 0,431 \\
\hline$\% 5-15-25 \mathrm{SPT}+\mathrm{AA}+\% 3 \mathrm{MAPE}$ & 0,864 & 13 & 0,044 \\
\hline$\% 5-15-25$ Kalsit $+\% 3$ MAPE & 0,892 & 7 & 0,283 \\
\hline$\% 15-25$ Borik Asit + \%3 Silanil & 0,944 & 10 & 0,598 \\
\hline
\end{tabular}

Test sonucunda eğilme direnci bakımından kompozit türü olarak \%5-15-25 SPT + AA + \%3 MAPE grubu dışındaki diğer kompozit grupların önem düzeyi değerleri $\mathrm{P}>0,05$ olduğu için normal dağılım göstermektedir. Kompozit gruplarının eğilmede elastikiyet modülüne ait tanımlayıcı istatistikler Tablo 22'de gösterilmiştir. 
Tablo 22. Eğilmede elastikiyet modülü hesaplanan kompozit çeşitlerinin tanımlayıcı istatistik değerleri

\begin{tabular}{cccccc}
\hline $\begin{array}{c}\text { Kompozit } \\
\text { Çeşidi }\end{array}$ & $\begin{array}{c}\text { Kompozit } \\
\text { Sayısı } \\
(n)\end{array}$ & Ort. & $\begin{array}{c}\text { Standard } \\
\text { Sapma } \\
(\text { Std })\end{array}$ & $\begin{array}{c}\text { Minimum } \\
\text { Değerler }\end{array}$ & $\begin{array}{c}\text { Maksimum } \\
\text { Değerler }\end{array}$ \\
\hline Tetrapak + Plastik & 10 & 7423,03 & 3368,79 & 3629,74 & 15219,11 \\
\hline \%5-15-25 Kalsitli & 12 & 468,01 & 209,10 & 143,56 & 816,32 \\
\hline $\begin{array}{c}\text { Tetrapak + Plastik + } \\
\text { \%3 Titanat }\end{array}$ & 4 & 435,41 & 165,68 & 234,67 & 598,35 \\
\hline $\begin{array}{c}\text { \%5-15-25 Kalsit + \%3 } \\
\text { Titanat }\end{array}$ & 12 & 323,84 & 173,74 & 97,18 & 604,53 \\
\hline $\begin{array}{c}\text { \%5-15 SPT + AA + } \\
\text { \%3 Titanat }\end{array}$ & 8 & 480,51 & 160,53 & 163,55 & 682,53 \\
\hline $\begin{array}{c}\text { \%5-15 Borik Asit + } \\
\text { \%3 MAPE }\end{array}$ & 8 & 3574,68 & 1828,43 & 508,93 & 5580,32 \\
\hline $\begin{array}{c}\text { \%5-15-25 SPT + AA + } \\
\text { \%3 MAPE }\end{array}$ & 13 & 1916,26 & 1428,88 & 364,80 & 4758,18 \\
\hline $\begin{array}{c}\text { \%5-15-25 Kalsit + \%3 } \\
\text { MAPE }\end{array}$ & 7 & 3414,53 & 2764,50 & 531,87 & 7453,30 \\
\hline$\% 15-25$ Borik Asit + \\
\%3 Silanil
\end{tabular}

Tanımlayıcı istatistik tablosunda her bir kompozit çeşidinde kaç örnek bulunduğu, bunların ortalamadeğerleri ile bunlara ait standart sapma değerleri yer almaktadır. Tabloda kompozit çeşitlerinin içerdikleri katkı maddeleri ve kimyasal çeşitleri arttıkça elastikiyet modüllerinin arttığı görülmektedir. Elastikiyet modülleri bakımından kompozit çeşitleri varyans analizi ile karşılaştırılmış ve sonuçlar Tablo 23'de gösterilmiştir.

Tablo 23. Varyans Analizi tablosu

\begin{tabular}{cccccc}
\hline & Kareler Toplamı & $\begin{array}{c}\text { Serbestlik } \\
\text { Derecesi } \\
(d f)\end{array}$ & Ortalama Kare & F & $\begin{array}{c}\text { Önem } \\
\text { Düzeyi }\end{array}$ \\
\cline { 1 - 4 } $\begin{array}{c}\text { Gruplar } \\
\text { Arası }\end{array}$ & 413435079,6 & 8 & 51679384,95 & & \\
\cline { 1 - 3 } $\begin{array}{c}\text { Gruplar } \\
\text { İçi }\end{array}$ & 210617875,0 & 75 & 2808238,333 & & 0,000 \\
\cline { 1 - 3 } Toplam & 624952954,6 & 83 & & & \\
\hline
\end{tabular}

Anova tablosunda önem düzeyi $\mathrm{P}<0,05$ olduğu için gruplar arasında incelenen eğilme dirençleri bakımından istatistik anlamlı ve önemli bir fark olduğu görülmektedir. Hangi grupların ortalama değerleri arasında farklılıklar olduğu Tamhane T2 testi ile belirlenmiştir.

\section{SONUC}

Takviye eleman ve matris malzeme ile arayüzey uyumu oluşturulan kompozit malzemenin mekanik özellikleri direnç yönünden oldukça iyi davranış göstermektedir.

Odun plastik kompozitlerinde kullanılan uyum sağlayıcı maddeler, polar olan odun lifleri ile polar olmayan polimerik materyaller arasındaki uyumu maksimum seviyeye getirmede önemli rol oynar. Katkı maddeleri ve birleştirici maddeler esas olarak fiziksel ve mekanik özellikler üzerine etkilidir. Bu katkı maddeleri veya birleştirici kimyasallar değiştirilerek oluşturulan ürün performansı geliştirilebilir. 
Eğilme direnci (MOR) istatistiksel bulgularının verdiği sonuçlara göre; Tetrapak + Plastik grubunun eğilmede elastikiyet modülü üzerine; Tetrapak + Plastik grubunun eğilmede elastikiyet modülü üzerine; Tetrapak + Plastik + BA + Titanat, Tetrapak + Plastik + Kalsit + Titanat, Tetrapak + Plastik + $\mathrm{SPT}+\mathrm{AA}+$ Titanat,Tetrapak + Plastik + BA + MAPE, Tetrapak + Plastik + BA + Silanil gruplarında anlamlı farklılıklar gösterdiği belirlenmiştir. Tetrapak + Plastik kompozitlerin kırılma direnci üzerine kompozitlere eklenen eşleştirici kimyasal madde çeşidi etkisinin genel olarak farkl1lık oluşturduğu gözlemlenmiştir. Kalsit eklenmiş kompozit gruplarının ise diğer gruplarla eğilme direnci üzerine aralarında anlamlı bir fark olmadığı tespit edilmiştir. Tetrapak + Plastik karışımına Borik Asit eklenmiş gruplar kırılma direnci bakımından Borik Asit + Titanat ve Borik Asit + MAPE eklenmiş kompozit gruplarla aralarında anlamlı bir fark olduğu belirlenmiştir. SPT + AA eklenmiş kompozit grubunun kırılma direnci üzerine kimyasal madde eklenmiş diğer kompozit gruplarıyla aralarında anlamlı bir fark olmadığı tespit edilmiştir. Benzer şekilde Titanat eklenmiş kompozit grubun da kırılma direnci bakımından diğer gruplarla karşılaştırıldığında aralarında anlamlı bir fark olmadığı tespit edilmiştir. Borik Asit + Titanat eklenerek üretilen kompozit grubunun kırılma direnci Borik Asit eklenmiş kompozit gruptan ve sadece Tetrapak + Plastikten oluşan gruplardan farklıdır. Kalsit ve Titanat eklenmiş grubun kırılma direnci kimyasal bağlayıcı ajan eklenmemiş Tetrapa + Plastik kompozit grubu ile farklılık göstermektedir. Tetrapak + Plastik karışıma SPT + AA + Titanat eklenmiş kompozit grubunun kırılma direnci değerleri Tetrapak + Plastik grubu ile farklılık göstermiştir. Borik Asit + MAPE eklenmiş kompozit grubu hiç kimyasal madde eklenmemiş grup ve Borik Asit eklenmiş kompozit grubu ile anlamlı bir fark göstermiştir. Borik Asit + Silanil eklenmiş kompozit grubu hiç kimyasal madde eklenmemiş Tetrapak + Plastik kompozit grubu ile kırılma direnci değerleri bakımından farklı olduğu tespit edilmiştir.

Eğilmede elastikiyet modülü (MOE) istatistiksel bulgularının verdiği sonuçlara göre ise; Test sonuçları incelendiğinde Tetrapak + Plastik grubunun eğilmede elastikiyet modülü üzerine; Tetrapak + Plastik + Kalsitli, Tetrapak + Plastik + Titanatl, Tetrapak + Plastik + Kalsitli + Titanatl1, Tetrapak + Plastik + SPT + AA + Titanatll, Tetrapak + Plastik + SPT + AA + MAPE, Tetrapak + Plastik + BA + Silanil gruplarında anlamlı farklılıklar gösterdiği belirlenmiştir. Tetrapak + Plastik kompozitlerin eğilmede elastikiyet modülü üzerine kompozitlere eklenen eşleştirici kimyasal madde çeşidi etkisinin genel olarak farklılık oluşturduğu gözlemlenmiştir. Ancak Tetrapak + Plastik grubunun Tetrapak + Plastik + BA + MAPE ve Tetrapak + Plastik + Kalsit + MAPE grupları ile benzer elastikiyet modülü değerleri gösterdiği ve anlamlı farklılık oluşturmadığı belirlenmiştir. Benzer durumda, Tetrapak + Plastik + Kalsitli kompozit grubunun eğilmede elastikiyet modülü üzerine Tetrapak + Plastik ve Tetrapak + Plastik + BA + Silanil gruplarıyla anlamlı farklılık gösterdiği tespit edilmiştir. Tetrapak + Plastik + Kalsitli kompozit grubu, Tetrapak + Plastik + Titanat, Tetrapak + Plastik + Kalsit + Titanat, Tetrapak + Plastik + SPT + AA + Titanat, Tetrapak + Plastik + BA + MAPE, Tetrapak + Plastik + $\mathrm{SPT}+\mathrm{AA}+\mathrm{MAPE}$, Tetrapak + Plastik + Kalsit + MAPE kompozit çeşitleriyle elastikiyet modülü bakımından benzerlikler göstermektedir. Tetrapak + Plastik + Titanat kompozit çeşidi eğilmede elastikiyet modülü üzerine, Tetrapak + Plastik ve Tetrapak + Plastik + BA + Silanil kompozit gruplarıyla anlamlı farklılık gösterdiği tespitedilmiştir. Diğer taraftan Tetrapak + Plastik + Titanat kompozit çeşidi eğilmede elastikiyet modülü bakımından, Tetrapak + Plastik + Kalsitli, Tetrapak + Plastik + Kalsit + Titanat, Tetrapak + Plastik + SPT + AA + Titanat, Tetrapak + Plastik + BA + MAPE, Tetrapak + Plastik + SPT + AA + MAPE ve Tetrapak + Plastik + Kalsit + MAPE kompozit çeşitleriyle benzerlik gösterdiği tespit edilmiştir. Tetrapak + Plastik kompozit malzemesinin Kalsit ve Titanatla güçlendirildiği kompozit çeşidi, eğilmede elastikiyet modülü bakımından eklenen kimyasal madde çeşidinin etkisi sadece kimyasal madde katılmamış olan Tetrapak + Plastik ve Tetrapak + Plastik + BA + Silanil kompozit çeşidinde anlamlı bir farklılık gösterdiği tespit edilmiştir. Tetrapak + Plastik + Kalsit + Titanat kompozit çeşidi, Tetrapak + Plastik + Kalsitli, Tetrapak + Plastik + Titanatll, $\mathrm{SPT}+\mathrm{AA}+$ Titanat katk1l1, BA + MAPE katk1lı, SPT + AA + MAPE katkı1 ve Kalsit + MAPE katkılı kompozit malzeme çeşitleriyle benzerlik göstermektedir. SPT + AA + Titanat katkılı Tetrapak + Plastik kompozit malzeme çeşidi, eğilmede elastikiyet modülü bakımından eklenen kimyasal madde çeşidi etkisi, sadece Tetrapak + Plastik kompozit çeşidiyle anlamlı bir farklılık gösterdiği belirlenmiştir. Aynı kompozit çeşidi, Kalsit, Titanat, Kalsit + Titanat, BA + MAPE, SPT + AA + 
MAPE, Kalsit + MAPE ve BA + Silanil katkılı kompozit çeşitleriyle anlamlı bir farklılık göstermemektedir. BA + MAPE ilave edilen kompozitler, eğilmede elastikiyet modülü üzerine kimyasal madde çeşidi etkisi, karşılaştırıldığı hiçbir grupta anlamlı bir fark oluşturmamıştır. Bu kompozit çeşidi, Tetrpak + Plastik, Kalsitli, Titanat, Kalsit + Titanat, SPT + AA + Titanat, SPT + AA + MAPE, Kalsit + MAPE ve BA + Silanil katkılı kompozit malzeme çeşitleriyle anlamlı bir farklılık oluşturmadığ 1 tespit edilmiştir. SPT + AA + MAPE katkılı kompozit malzeme çeşitlerinin eğilmeden elastikiyet modülü üzerine eklenen kimyasal madde çeşidi farklılıklarının etkisi sadece Tetrapak + Plastik grubu arasında anlamlı bir fark göstermektedir. BA + Silanil katk1lı kompozit grubu ile Tetrapak + Plastik, Kalsitli, Titanatlı, ve Kalsit + Titanatlı gruplar arasında eğilmede elastikiyet modülü değerleri arasında anlamlı bir fark olduğu tespit edilmiştir. Odun plastik kompozitlerin mekanik özelliklerinin değerlendirildiği bir çalışmada; parça kesit boyutlarının artması ile eğilme dayanımının azaldığı, mekanik özelliklerinin standart sapmalarının parça kesit boyutlarının daha büyük olduğu kompozit örneklerinde daha yüksek değerlerde çıktığı belirtilmiştir [7].

Termoplastik olan Yüksek Yoğunluklu Polietilen, atık pirinç sapları ve bağlayıcı olarak Maleik Anhidritle Kraft edilmiş Polietilen (MAPE)'nin kullanılarak kompozit malzemelerin üretildiği bir çalışmada; öğütülen lignoselülozik atık pirinç saplarına YYPE eklenmesiyle üretilen kompozitlerin mekanik ve fiziksel özelliklerinin göreceli olarak iyileştiği gözlemlenmiştir. Pirinç sapı miktarının artması eğilme direncini çok arttırmadığı ancak \%50 pirinç sapı içeren örneklere \%2 MAPE eklenmesi eğilme direncini önemli ölçüde arttırdığı belirtilmiştir [8]. Bu çalışmada ise MAPE ve Borik Asit'in bir arada kullanılması sadece tetrapaktan üretilen kompozitlere göre eğilme direncinde düşüşe sebep olmuştur. MAPE oranı sabit kalıp, Borik Asit oranı azaldıkça eğilme direncinde artma gözlemlenmiştir.

\%40-70 aralığında değişen oranlarda odun lifleri ve Yüksek Yoğunluklu Polietilen (YYPE) kullanılarak üretilen kompozit malzemelerin mekanik özelliklerinin araştıııldığı bir çalışmada, ayrıca bağlayıcı ajan Maleik Anhidritle Kraft edilmiş Polietilen (MAPE) eklenerek de sonuçlar gözlemlenmiştir. Buna göre bağlayıcı ajan olmayan örnek grupları için kompozit malzeme içeriğindeki odun lifi miktarının artması eğilme direncini azaltırken elastikiyet modülü değerini artırmıştır. Ancak bağlayıcı ajan MAPE eklenmesi mekanik özellikleri önemli düzeyde iyileştirmiş [9]. Atık kağıt ya da odun lifi kompozit üretiminde çeşitli oranlarda kullanılabilir. Fakat yapılan diğer çalışmalar da göstermektedir ki bağlayıcı ajan kullanımının mekanik özelliklere olumlu yönde etkisi büyüktür.

Atık Tetrapak kağıtları ve farklı oranlarda maleik anhidrile kraftlanmış polietilen (MAPE)'den oluşturulan kompozit malzemelerin mekanik özellikleri üzerine yapılan bir çalışmada; maksimum eğilme direnci ve elastikiyet modülü \%30 Tetrapak ve \%3 MAPE içeren kompozitlerde gözlendiği belirtilmiştir. MAPE uyumlayıcı ajanının yapışmayı kolaylaştırarak kompozitlerin mekanik mukavemeti üzerinde olumlu etki yaptığı belirtilmiştir [10]. MAPE bağlayıcı ajanı kullanılarak yapılan çalışmalar Tetrapak boyutlarının küçültülmesi ile fiber ve matris malzeme bağlanmasının arttı̆̆ını desteklemektedir. Bu çalışma ile farklı bağlayıcı ajan (MAPE) oranlarının mekanik dirence büyük ölçüde katkı sağladığı tespit edilmiştir.

Üretilen kompozit malzeme çeşitleri içinde farklı oranlarda takviye malzemesi olarak kullanılan toz kalsitle, kompozitte alev almaya karşı dayanıklılığın arttırılması amaçlanmıştır. Bu fikrin sonucu olarak üretim esnasında yüksek sıcaklık ve basınç altındaki kalsitli örneklerde yüzeylerde yanık lekeleri hiç oluşmamıştır. Diğer örneklere nispeten daha temiz yüzeyler elde edilmiştir.

Çalışmada üretilen kompozit malzeme türlerinden Spt ( Sodyum Perborat Tetrahidrat) ile üretilenlerde genel olarak görülen dezavantaj mekanik dayanımın düşük olmasıdır. Spt ile istenilen birleştiricilik özelliği kompozit malzemeyi fiziksel ve mekanik yönde olumsuz etkilemiştir. 
TEȘEKKÜR: Bu çalışma doktora tezine dayanmaktadır, Bilimsel Araştırma Projesi (Bap) olarak desteklenmiştir. (Proje No: 4751-D1-16)

\section{KAYNAKLAR}

[1] G.Y1lmaz. "Effects of titanate coupling agents on low density polyethylene and polypropylene blendsand composites" M.S. thesis, The Graduate School of Natural and Applied Sciences,Middle East Technical University, Turkey, 2008.

[2] C. Ataş ve A. U. Öztürk. (2016, 2 Mayıs). "Modern kompozitler" [Online]. Erişim: http://www.ae2project.com/modern-kompozitler/.

[3] A. P. Mathew and K. Oksman, "Mechanical Properties of Biodegradable Composites From Poly Lactic Acid (PLA) And Microcrystalline Cellulose (MCC)", Journal of Applied Polymer Science, vol. 97, no. 5, pp. 2014-2025, 2005.

[4] N. Küçükdoğan, S. Halis, M. Sütçü, M. Sarıkanat, Y. Seki ve K. Sever. "Kağıt Üretim Atığ1 Katkılı Yüksek Yoğunluklu Polietilen (Yype) kompozitlerin mekanik özelliklerinin incelenmesi," Pamukkale Üniversitesi Mühendislik Bilimleri Dergisi, c. 23, ss. 949-953, 2017.

[5] M. Tufan, T. Güleç, U. Çukur, S. Akbaş ve S. İmamoğlu, "Atık bardaklardan üretilen odun plastik kompozitlerin bazı özellikleri," Kastamonu Üni., Orman Fakültesi Dergisi, c. 15, s. 2, ss. 176$182,2015$.

[6] Y. Tonta, (2008). Varyans Analizi (ANOVA), Kovaryans Analizi (ANCOVA), Faktöriyel ANOVA, Çoklu Varyans Analizi (MANOVA) [Online]. Erişim:http://yunus.hacettepe.edu.tr/ tonta/courses/fall2007/sb5002/sb5002-10-varyans-analizi.pdf.

[7] C. Gozdecki, A. Wilczynski, M. Kociszewski, J. Tomaszewska and S. Zajchowski, "Mechanical properties of wood-polypropylene composites with industrial wood particles of different sizes", Wood and Fiber Sciences, vol. 44, no. 1, pp.14-21. 2012.

[8] H. Acar, T. Salan, E. Altuntaş ve M. H. Alma, "Yüksek Yoğunluklu Polietilen (YYPE) ve atık pirinç saplarından üretilen kompozitlerin bazı mekanik ve fiziksel özelliklerinin belirlenmesi ", II. Ulusal Akdeniz Orman Ve Çevre Sempozyumu, Akdeniz Ormanlarının Geleceği: Sürdürülebilir Toplum ve Çevre, Isparta, Türkiye, 2014.

[9] E. Altuntaş, E. Yılmaz, T. Salan, "Yüksek oranda lif dolgu maddesi kullanımının odun plastik kompozit malzemenin mekanik özellikleri üzerine etkisinin araştırılması," Türkiye Ormancıllk Dergisi, c. 18, s. 3, ss. 258-263, 2017.

[10] M. Ebadi, M. Farsi and P. Narchin, "Some of the physical and mechanical properties of composites made from Tetra Pak ${ }^{\mathrm{TM}} / \mathrm{LDPE}$, Journal of Thermoplastic Composite Materials, vol. 31, no. 8, pp. 1054-1065, 2018. 